\title{
Tacy jak my
}

Images

vol. X/no. 19

Poznań 2012

ISSN 1731-45OX
Kilkanaście lat temu nakręcono w Australii Takich jak my, jeszcze wcześniej Robert Altman wyreżserował Złodziei takich jak my, z kolei w połowie lat 90. na ekrany kin weszli Nie tacy jak my Dave’a Paynea. O Ludziach takich jak my traktował też jeden $\mathrm{z}$ seriali BBC, a Szpiedzy tacy jak my, obraz zrealizowany przed ćwierćwieczem, do dziś pojawia się w telewizji. Wspólny mianownik niniejszych tytułów filmowych nie wydaje się być trudny do odnalezienia. „Tacy jak my” bądź też "nie tacy jak my” to nie tylko popularna fraza w tytule, ale również uniwersalny temat podejmowany od zarania kinematografii w różnych ujęciach, od wspomnianego (i najprostszego) zawierającego się w tytułach, przez pokazywanie odmienności z socjologicznego punktu widzenia (choćby pierwsze rejestracje filmowe zaspokajające głód nowości i pokazujące ludzi innych niż znani z otoczenia), czy też budowanie napięć na linii filmowy antagonista lub protagonista widz (człowiek taki jak/człowiek inny niż), aż do kreowania owego konfliktu wyłącznie w ramach filmowego świata.

Trzy etiudy studentów łódzkiej Szkoły Filmowej, o których będzie mowa, łączy właśnie ten ostatni sposób. Fabularne Opowieści $z$ chłodni (reż. Grzegorz Jaroszuk), animacja Drżące trąby (reż. Natalia Brożyńska) i dokument Niewidzialna granica (reż. Haukur M. Hrafnsson), dotykają kwestii poszukiwania oraz podawania w wątpliwość zbieżności zachodzących między ludźmi.

Etiuda Grzegorza Jaroszuka wprowadza widzów w błękitny świat chłodni, którego siłą są intrygujący bohaterowie: Ona (Justyna Wasilewska) - po nieudanej próbie samobójczej, z substytutem męża, kotem-alkoholikiem, On (Piotr Żurawski) - mężczyzna pozbawiony poczucia własnego ,ja”, zazwyczaj mylony z kimś innym, Kierownik (Andrzej Walden) - bóg chłodniowego światka, wyższa instancja dbająca o swoich podwładnych. Opowieści $z$ chłodni to historia dwójki najgorszych pracowników supermarketu, którym postawione zostaje ultimatum: albo znajdą cel w życiu, albo zostaną zwolnieni z pracy. Nie chcąc stracić posady, oboje definiują swój cel jako udział w programie „Najnieszczęśliwszy człowiek miesiąca”. Ich staraniom przygląda się Kierownik, który, usiłując pomóc w spełnieniu życiowego marzenia bohaterów, wciąż kontroluje ich stan emocjonalny, przerywa najkrótsze bodaj chwile szczęścia. Niespodziewanie jednak między kobietą a mężczyzną zarysowuje się więź. Porozumienie początkowo wynika z sytuacji, w jakiej oboje się znajdują: zagrożeni utratą posady, najgorsi pracownicy, podlegli woli Kierownika. Stopniowo ich relacja
Ludzie tacy jak my:

Opowieści

zchłodni 
umacnia się. Dla stworzenia bliskości kluczowe jest jednak zrozumienie ukrytych przyczyn łączącego oboje nieszczęścia.

Przełomowy dla bohaterów okazuje się wniosek, że życie mężczyzny jest takie jak egzystencja kobiety, a codzienność kobiety taka jak mężczyzny. Oboje pragną przede wszystkim zrozumienia oraz wzajemnej akceptacji, obejmującej w pierwszym rzędzie dręczące ich problemy. Punktem zwrotnym będzie więc z jednej strony chwila, w której okaże się, iż kobieta rozpoznaje mężczyznę jako jego samego, że jest pierwszą poza nim osobą, która z nikim go nie myli, oraz - tym razem z drugiej strony - zorganizowanie przez mężczyznę odwyku dla kota-alkoholika. Z czasem kobietę i mężczyznę zaczyna łączyć, jeśli nie uczucie, to przynajmniej kojące przeświadczenie o podobieństwie do drugiej osoby. Odnajdują się oni w sobie i we wzajemnym nieszczęściu, a owo niespodziewane wrażenie wspólnoty daje im siłę, by próbować wyrwać się z błękitnego, zamrożonego świata.

Samo zakończenie, moment, w którym kobieta oraz mężczyzna podejmują decyzję i odrzucając wybrany naprędce cel, rezygnują tym samym $z$ dotychczasowej, zamrożonej egzystencji, daje bohaterom - a przy okazji również widzom - nadzieję. Nawet nieszczęście potrafi zbliżyć, przecież każdemu z nich udało się odnaleźć w zimnym świecie kogoś podobnego do siebie. Nic więc dziwnego, że uśmiechają się, opuszczając chłodnię.

Stwory takie jak my: Drżące trąby
Natalia Brożyńska proponuje widzom animowaną historię relacji Pafnucego - włochatego stwora $\mathrm{z}$ lateksową trąbą i problemami z koordynacją ruchową, z Kalasantym, jego przeciwieństwem - bezwłosym stworzeniem o całkiem zwyczajnym, niewielkim nosie. Zaczynając jednak od początku: Pafnucek za wszelką cenę usiłuje przyjąć utrwaloną na zdjęciu, triumfalną (jego zdaniem) pozę Kalasia, pozę „człowieka sukcesu”. Nie udaje mu się to ze względu na różnice anatomiczne. Niemożność dorównania Kalasantemu wywołuje wściekłość futrzaka, który łapie siekierę i na wrotkach zmierza do mieszkania swego „wroga”. W tym samym czasie Kalasanty roniąc łzy rozpaczy, usiłuje dorównać wspaniałej (w swoim mniemaniu) sylwetce Pafnucka. Ubiera więc włochate futro i zawiązuje sobie na twarzy trąbę. Tak jak jeden stwór chciałby być drugim, tak drugi marzy o byciu na miejscu pierwszego. Dlatego też, gdy Pafnucy dzwoni do drzwi, a Kalasanty otwiera w przebraniu Pafnucka, zamiast konfrontacji następuje przełom.

Rozwiązanie zaproponowane przez reżyserkę, czyli wzajemne pojednanie, wzrusza stwory, a także oddziałuje na widzów. Podczas gdy tytułowe drżące trąby faktycznie drżą i siąkają, bohaterowie zyskują świadomość, że więcej ich łączy, niż dzieli. „A więc ty jesteś taki, a ja myślałem, że ty jesteś owaki... Ja ci tak zazdrościłem przez cały czas, a ty też płakałeś... Ładny kombinezon, fajna rura od odkurzacza... Przyjechałeś do mnie z siekierą, znaczy, że też nie jestem ci obojętny.... Wzajemna niechęć spowodowana różnicami wynikłymi 
z niezrozumienia odchodzi w cień. Innymi słowy: dla przyjaźni między Pafnucym a Kalasantym nie ma przeciwwskazań.

Animacja Brożyńskiej w zabawny i ciepły sposób dotyka problemu pozornych różnic, zazdrości oraz poszukiwań bratniej duszy. Oba stwory cierpią z powodu niezrozumienia. Choć na pierwszy rzut oka głównym motorem działań Pafnucego i Kalasia wydaje się być zazdrość, to jednak problem sięga znacznie głębiej. Pafnucy pragnie upodobnić się do Kalasantego, by finalnie znaleźć z nim wspólny język. Tak samo i Kalasanty przywdziewając specjalny kombinezon, który ma dać mu złudne poczucie podobieństwa do Pafnucego, $\mathrm{w}$ istocie łaknie jego sympatii. Jak się więc okazuje, tym, co najważniejsze, nie jest ani „poza człowieka sukcesu”, ani rura od odkurzacza zwana trąbą.

Układ odniesień między bohaterami trzeciego filmu stoi niejako w opozycji do dwóch omówionych wcześniej. Problem poruszony w dokumencie Haukura M. Hrafnssona dotyczy codziennej konfrontacji ludzi mieszkających na tej samej ulicy. Podczas gdy jedną stronę ulicy Cyganka zamieszkują młodzi, zamożni przedstawiciele klasy średniej, druga strona tej samej drogi należy do osób ubogich, często żyjących wspomnieniami poprzednich epok. Szczególnie interesujący w etiudzie jest sposób przedstawienia obu nieprzystających do siebie środowisk. Hrafnsson pokazuje mieszkańców Cyganka poprzez ich domy, zniszczone budynki i zarośnięte trawą podwórka albo wypielęgnowane, acz wysoko i starannie odgrodzone od reszty świata wille. Tytułowych „niewidzialnych granic” jest wiele: od oczywistej kwestii finansowej, różnic w podejściu do życia i wychowania potomstwa, do inaczej definiowanych celów życiowych. Na pierwszy rzut oka wydaje się jednak, że kwintesencją tego, co skłóca mieszkańców Cyganka, jest całkowity brak podobieństwa między przedstawicielami każdej ze stron. W pewien sposób, z perspektywy samych bohaterów, jest to nawet prawda. Inność, niemożność kompromisu czy zwyczajnego porozumienia wynika $z$ faktu, że każda ze stron wierzy, iż oni (druga część ulicy) są od nich inni. Podział na strefy wytyczony jest bardzo wyraźnie. Być może najlepszym przykładem będą dzieci, którym może i wprost nie zabrania się bawić razem, lecz które i tak wybierają towarzystwo odpowiedniej części Cyganka.

Drugie zarzewie konfliktu jest nieco bardziej skomplikowane i dość paradoksalne. Choć działająca w obu środowiskach opozycja „my i oni” stwarza poczucie całkowitej odrębności, nie sposób przejść obojętnie wobec faktu, że zarówno gorzej sytuowani mieszkańcy, jak i właściciele bogatych rezydencji są jednak, w najsilniejszych emocjach, do siebie podobni. Łączy ich zawziętość w odgradzaniu się od drugiej strony, zapalczywe podejście do sąsiadów, antagonizm wobec innego statusu majątkowego i stylu życia. Sama możliwość bycia „takimi jak oni” jest prawdopodobnie największym dramatem dla każdej ze stron. Tym gorzej, że owa nieuświadamiana zbieżność stop-

Oni inni niż my: Niewidzialna granica 
niowo wychodzi na jaw. Zgrabny montaż co rusz podsuwa widzom zbliżone w swojej wymowie wypowiedzi mieszkańców obu części ulicy. Wydaje się, że w tej właśnie obserwacji zawiera się wartość Niewidzialnej granicy. Jak pokazuje przykład ulicy Cyganka, nawet ludzie rzekomo inni niż my, w gruncie rzeczy pozostają do nas niezwykle podobni.

Choć powyżej opisane etiudy studentów łódzkiej Filmówki dzieli niemal wszystko: filmowy rodzaj, stylistyka opowiadanej historii, kreacja bohaterów itd., trójka młodych reżyserów zaproponowała widzom filmy poruszające ten sam problem. Poprzez swoje obrazy Jaroszuk, Brożyńska i Hrafnsson próbują przypomnieć o tym, że w naturze ludzkiej leży nieustanne poszukiwanie podobieństw międzyludzkich, porównywanie innych i siebie oraz przełamywanie barier wynikających z pozornej odmienności. Opowieści z chłodni, Drżace trąby oraz Niewidzialna granica to filmy o rodzeniu się poczucia zbieżności i bliskości z innymi ludźmi, o jego odkrywaniu, ale też wypieraniu się go. Owo wskazywanie na podobieństwa, odnajdywanie nieoczekiwanej wspólnoty, ujawnianie, że w gruncie rzeczy wszyscy jesteśmy jednakowi, bądź też odwrotnie - odżegnywanie się od choćby możliwości porównania siebie $\mathrm{z}$ inną osobą, stanowi esencję wielu obrazów twórców młodego pokolenia. Szczęśliwie jednak żaden z głosów podejmujących temat „takich jak my” nie jest taki jak inne. 